\title{
Greenhouse Gas Emissions of Food Waste Disposal Options for UK Retailers
}

4

5

6

7

8

9

10

11

\author{
J.A. Moulta, S.R. Allan', C.N. Hewitta, M. Berners-Leeb,c,*
}

\begin{abstract}
a Lancaster Environment Centre, Lancaster University, Lancaster LA1 4YQ UK
b Institute for Social Futures, Lancaster University, Lancaster LA1 4YQ, UK

c Small World Consulting Ltd, Lancaster Environment Centre, Lancaster University, Lancaster LA1 4YQ, UK
\end{abstract}




\section{Abstract}

14 Food retailers are under increasing political and social pressure to reduce both the amount of food that they waste and the amount of greenhouse gases (GHGs) that their food retailing activities incur. For completeness, when assessing the "carbon footprint" of their business activities, food retailers should also included the greenhouse gas emissions caused by their disposal of waste food, which will vary with the waste disposal option used. However, there is lack of quantitative guidance for food retailers on the net GHG emissions that are incurred in the disposal of specific food types by the various disposal options available. Here, we calculate the net GHG emissions of eight different waste disposal options for five core food types using life cycle assessment, accounting for both emissions incurred in transport and processing, and those mitigated by the creation of useful products. We also assess the extent to which the embodied emissions in waste foods at the retail checkout can be mitigated by each disposal option. In addition to food specific results, we calculate mass-weighted averages using data from a mid-sized retail chain. We find a strong correlation between net emissions and the energy density of foods, and the following mass weighted disposal hierarchy (from best to worst, with respect to greenhouse gas emissions): donation of edible food to food banks; anaerobic digestion; conversion to animal feed; incineration with energy recovery; aerobic composting; landfill with gas collection and utilisation; landfill with gas collection and flaring; landfill without gas collection. If waste food from retailers is unfit for human consumption, to minimise greenhouse gas emissions it should be disposed of by conversion to animal feed or anaerobic digestion. For all food types, landfill is the worst disposal option. 


\section{Key Words}

35

36

37

Food waste; Disposal options; Carbon footprint; Greenhouse gas emissions; Food retailers

\section{Introduction}

Food waste is major global problem with social, economic and environmental implications. Reducing food waste is a challenge faced by governments, charitable organisations, corporations and individuals alike, with the United Nations aiming to halve global food waste per capita at the retail and consumer level by 2030 (UN, 2015). Despite innovations in consumer demand modelling, storage, packaging and the use of price-cutting to reduce waste, some retail food waste is inevitable, leaving food retailers with decisions as to how to best dispose of this waste.

The disposal options available to a food retailer for any given food depend on several factors: the food's condition; whether the food's expiry date has passed; and whether the food is plantderived or contains components of animal origin. Where it is safe to do so, unsold foods can be donated for human consumption; however in Europe at least, foods that have spoiled or passed their 'use-by' date cannot be donated or redistributed for human consumption (European Commission, No 1169/2011). Foods unsuitable for human consumption can be used for animal feed, providing they do not present any health risks (European Commission, No 68/2013). The recycling of 'vegetal' foods (fruits, vegetables and cereal grains) as animal feed is generally encouraged (Wadhwa \& Bakshi, 2013), providing the foodstuff has not contacted animal products during its lifetime or spoiled (Lancashire County Council, 2016). The use and disposal of animal by-products (ABPs; foods no longer intended for human consumption consisting of or containing animal products) from food retailers is strictly regulated (European Commission, No 142/2011; European Commission, No 1069/2009), with only 'lower risk' ABPs (vegetarian bakery and confectionery 
products, milk and products, eggs and products, animal fats and fish oils) eligible for use as feed (DEFRA \& APHA, 2014b). Greater risk ABPs ('medium' risk foods containing cooked or fully precooked meat or fish products; and 'higher' risk foods containing raw, cured or partially cooked meat or fish products) can be sent to landfill (with a $20 \mathrm{~kg} /$ week limit applying to higher risk ABPs) (European Commission, No 142/2011). Other disposal options for food waste by retailers include conversion to pet food (except for higher risk ABPS) (DEFRA \& APHA, 2014c); rendering (ReFood, 2014); ensiling of fish wastes, incineration; anaerobic digestion; composting; land application (direct for egg and shellfish shells, after heat-treatment for all other ABPs) and conversion to fertilizer or soil approver (DEFRA \& APHA, 2014a).

Anaerobic digestion (controlled anoxic microbial degradation of organic matter) of commercial food waste is increasingly popular (Ariunbaatar, et al., 2016; Carlsson, et al., 2015). It is now generally favoured over composting as a means of processing commercial food waste (DEFRA, 2011a; ReFood, 2014), producing methane-rich biogas and nutrient rich digestate. Incineration is also growing in popularity (DEFRA, 2014) as a means of deriving energy from high-energy foodstuffs (San Martin, et al., 2016), particularly high risk ABPs (ReFood, 2014). Landfill remains a major enddestination for food waste from retail despite taxation (currently $f 84.40 /$ tonne in the UK) (HM Revenue \& Customs, 2016a) and incurring substantial methane emissions.

$$
\text { Annual food wastages by the UK retail sector are estimated at } 250 \mathrm{kt} \text { (WRAP, 2017). Of this, 2\% }
$$
is redistributed (donated) to people, $\sim 10 \%$ is converted to animal feed, and $\sim 30 \%$ is managed through each of recycling (anaerobic digestion and composting), recovery (incineration and landfill with energy recovery) and disposal (sewer and landfill without energy recovery) routes (WRAP, 2015). Such proportions are contrary to the objectives of food waste management hierarchies published by US and European government agencies (EPA, 2017; European Commission, 
A

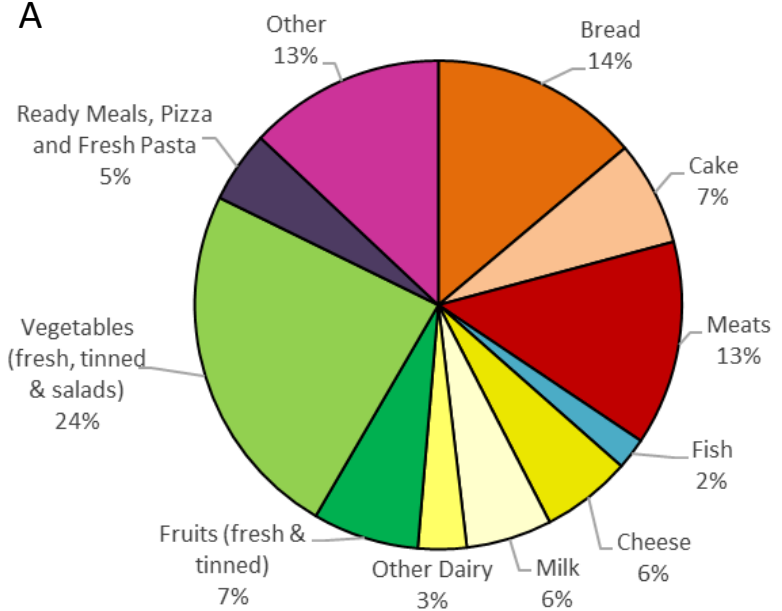

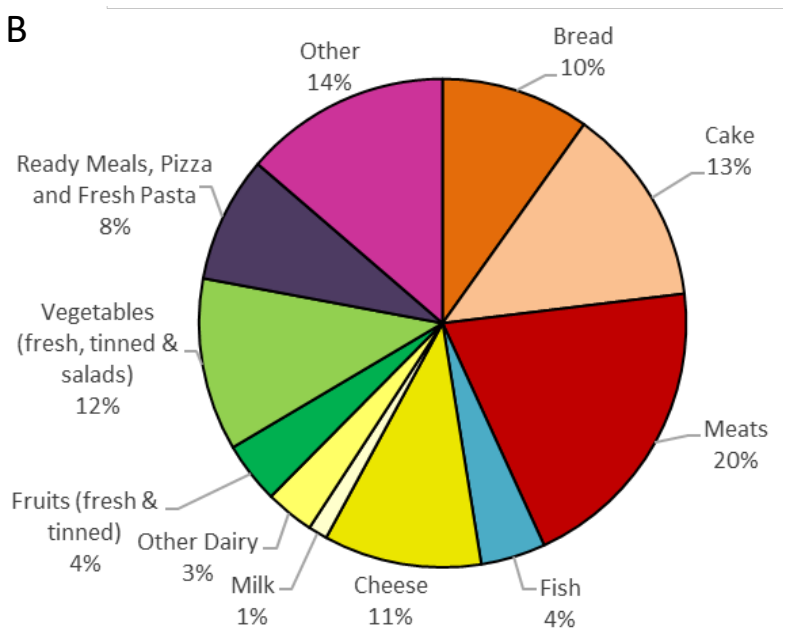

2008/98/EC) which encourage donation and conversion to animal feed whilst discouraging disposal to landfill and incineration.

Environmental impact is an integral factor influencing food waste management decisions made by retailers. These impacts can include GHG emissions, water use and pollution of water, air and soil systems. However, for this study we focus on GHG emissions only. The carbon footprint of any given food waste management pathway is inherently dependant on the composition of the food being disposed of and of the disposal pathway used. However, there is currently little information on foodtype specific waste management emissions for food retailers, with most published food waste management hierarchies being based on a heterogeneous mix of food waste.

In prior work, the food wastage from a mid-sized food retail chain in the UK was investigated (Figure 1). Bakery goods, dairy, fruit \& vegetables, meats and fish collectively accounted for $82 \%$ of waste by weight. Similar results were reported by a major food retailer, with bakery, fresh fruit and vegetable produce, dairy, meat and fish making up 74\% by weight of the chain's food waste in 2014 (Tesco, 2014).

Figure 1: Annual food retail waste from a mid-sized ( 28 outlets) supermarket chain in the UK, proportioned: a) by mass $(\mathrm{kg})$ b) by value (f). 
In this study, we evaluate the net greenhouse gas emissions resulting from the individual disposal of unsold bread, cheese, fruit and vegetables (F\&V), fish and meat from the point of potential sale in a supermarket through eight disposal options: donation of edible food to a food bank or redistribution charity for human consumption ('donation'); conversion to wet animal feed at a feed processing facility ('animal feed' or 'conversion to feed'); anaerobic digestion; composting; large modern UK landfill capturing $70 \%$ of produced methane (Gregory, et al., 2014); and global average landfill with 20\% methane capture (IPCC, 2006); landfill with no gas collection infrastructure. Some of these disposal options are hypothetical for certain foods, such as conversion to raw meat and fish to animal feed, due to the aforementioned regulations in the UK, but are included for completeness of GHG emissions.

\section{Methods and Data}

We employ a life cycle assessment (LCA) approach to evaluating net GHG emissions from each disposal option. We do not consider food-carbon returned to the atmosphere as carbon dioxide, since it was originally sequestered though photosynthesis, but do consider other emissions both incurred and mitigated at all stages of each disposal option, from transportation to processing facility or end of life destination. Our system boundaries are shown in Figure 2 and the assumptions used are listed in Table 1. GHG emissions are evaluated in terms of carbon dioxide equivalents per tonne of food waste $(\mathrm{kg} \mathrm{CO} 2 \mathrm{e} / \mathrm{t} \mathrm{FW})$. We use a global warming potential (GWP) of 25 for methane emissions (IPCC, 2007). Nutritional content/profile/chemical composition data and embodied carbon ( $E_{\text {store }}$ ) values for each food type are shown in Table 2 . $E_{\text {store }}$ values include all major life cycle stages up to the checkout: production, processing, transport, packaging and supermarket operations, and were obtained from previous work (Hoolohan et al., 2013). The emissions factors used to generate these values are detailed elsewhere (Berners-Lee \& Hoolohan, 2012). Emissions factors used in this analysis are detailed in Table 3. 


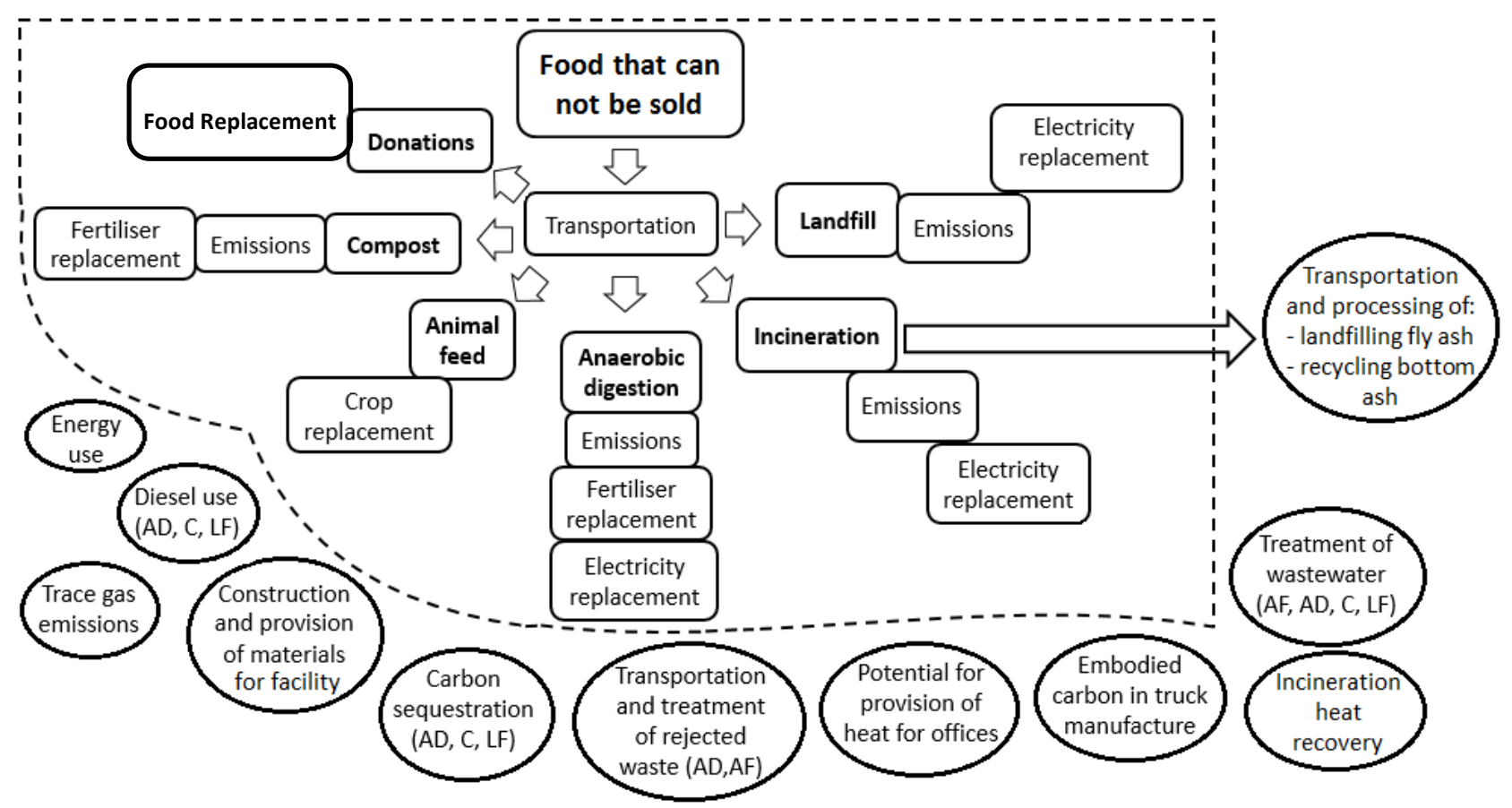

123 Figure 2 System boundaries for the LCA of food waste management pathways. Adapted from (Rajaeifar et al., 2015).

124 System boundary is denoted by the dashed line. AF- animal feed; AD- anaerobic digestion; C- compost; LF- landfill. 
Table 1 Assumptions used for all food waste disposal scenarios.

\section{Assumption}

All food masses were exclusive of food packaging.

Food waste separation was assumed to occur at the retail store, causing no emissions.

Transportation to the nearest available facility for each scenario was assumed.

All food waste processing systems process all received waste.

Round trip distance is approximate to the square root of the average land area served per disposal site.

Each leg of a transport route, i.e. the outward and return journeys, are identical in every respect.

Supermarkets and all process/end of life destinations are evenly distributed across the UK. Every site within one site type serves the same land area, with no overlap. Average land area served by each site is equal to the total UK land area divided by the number of the type of site.

All food is edible for humans, and thus also suitable for animal feed.

A refrigerated 3.5-7.5t heavy goods vehicle (HGV) is used for transport of perishable food types (cheese, meat and fish), whilst a non-refrigerated equivalent was used for semi-perishable foods (bread, fruit \& vegetables).

Mitigated emissions from consumption of the food $\left(M_{D}\right)$ is equal to the embodied emissions of the food at the supermarket ( $\left.E_{\text {store }}\right)$.

Food waste is transported in a 26 tonne HGV (akin to waste collection vehicles in common use across the UK)

Long term soil carbon sequestration from food compost and digestate is not significant.

No losses of nitrogen, phosphorous or potassium occurs during digestion.

For composting $6 \%$ losses of nitrogen $\left(1 \%\right.$ to $\mathrm{N}_{2} \mathrm{O}, 5 \%$ to $\left.\mathrm{NH}_{3}\right)$.

$100 \%$ of $\mathrm{CH}_{4}$ produced was assumed to be collected and converted to electricity on site.

Electricity and heat requirement for the anaerobic digestion process is approximately proportional to the total solids (TS) content of the foods (although the energy used is typically sourced from the process itself)

No fossil fuel-derived emissions were incurred in the incineration process.

\section{Relevant Scenario}

All

All

Donation, Animal Feed

Donation

Donation

All except donation

Anaerobic Digestion, Composting

Anaerobic Digestion

Composting

Anaerobic Digestion

Anaerobic Digestion

Incineration

Landfill 
Table 2 Nutritional content, chemical composition and embodied carbon emissions for each food type

\begin{tabular}{|c|c|c|c|c|c|c|}
\hline \multirow[t]{2}{*}{ Property } & \multicolumn{5}{|c|}{ Food Type } & \multirow[t]{2}{*}{ Reference(s) } \\
\hline & Bread & Cheese & $F \& V$ & Fish & Meat & \\
\hline Embodied Carbon $\left(\mathrm{kgCO}_{2} \mathrm{e} / \mathrm{t}\right)$ & 1400 & 13700 & 2500 & 2700 & 13800 & (Hoolohan et al., 2013) \\
\hline Energy (kcal/kg) & 2740 & 4040 & 369.5 & 1178.7 & 2187.5 & (FAO, 2016) (USDA, 2017) \\
\hline Protein $(\mathrm{g} / \mathrm{kg})$ & 106.7 & 228.7 & 10.2 & 192.8 & 152.9 & (FAO, 2016) (USDA, 2017) \\
\hline Kjedahl Nitrogen $(\mathrm{g} / \mathrm{kg})$ & 17.07 & 36.59 & 1.64 & 30.85 & 24.47 & (AOAC, 2000) \\
\hline Phosphorous (g/kg) & 1.29 & 4.55 & 0.31 & 2.05 & 1.58 & (FAO, 2016) (USDA, 2017) \\
\hline Potassium (g/kg) & 14.1 & 0.76 & 3.65 & 3.60 & 2.31 & (FAO, 2016) (USDA, 2017) \\
\hline Water (\%) & 35 & 37 & 85 & 75 & 66 & (USDA, 2017) (USDA, 2013) \\
\hline Total Solids, TS (\%) & 65 & 63 & 15 & 25 & 33 & Calculated from USDA data on water content \\
\hline Volatile Solids/Total Solids, VS/TS & 0.87 & 0.95 & 0.95 & 0.98 & 0.98 & (Carlsson \& Uldal, 2009) \\
\hline Specific methane potential ( $\mathrm{m}^{3} \mathrm{CH} 4 / \mathrm{t} \mathrm{VS}$ ) & 350 & 520 & 666 & 930 & 930 & (Carlsson \& Uldal, 2009) \\
\hline
\end{tabular}


Table 3 Emissions Factors for all Scenarios

\begin{tabular}{|c|c|c|c|}
\hline Emissions Factor & Emissions & Relevant Scenario(s) & Reference(s) \\
\hline Transport, Rigid HGV (>3.5 - 7.5 tonnes) & $0.64 \mathrm{kgCO}_{2} \mathrm{e} /(\mathrm{km} \mathrm{t} \mathrm{FW})$ & Donation: Bread and F\&V & (BEIS, 2017b) \\
\hline $\begin{array}{l}\text { Transport, Rigid HGV (>3.5 - } 7.5 \text { tonnes), } \\
\text { Refrigerated }\end{array}$ & $0.77 \mathrm{kgCO}_{2} \mathrm{e} /(\mathrm{km} \mathrm{t} \mathrm{FW})$ & Donation: Cheese, Fish and Meat & (BEIS, 2017b) \\
\hline Transport, Rigid HGV (>17 tonnes) & $0.20 \mathrm{kgCO}_{2} \mathrm{e} /(\mathrm{km} \mathrm{t} \mathrm{FW})$ & All except Donation & (BEIS, 2017b) \\
\hline Food to Feed Process & $7.28 \mathrm{kgCO}_{2} \mathrm{e} / \mathrm{t} \mathrm{FW}$ & Animal Feed & (Kim \& Kim, 2010; Takata, et al., 2012) \\
\hline Embodied emissions in animal feeds & $\begin{array}{l}\text { Oats: } 380 \mathrm{kgCO}_{2} \mathrm{e} / \mathrm{t} \\
\text { Soybean Meal: } 2700 \mathrm{kgCO}_{2} \mathrm{e} / \mathrm{t}\end{array}$ & Animal Feed & (Mogensen, et al., 2012) \\
\hline $\begin{array}{l}\text { Parasitic Electricity and Heat requirement of } \\
\text { the anaerobic digestion process for } \\
\text { heterogeneous food waste }\end{array}$ & $82.83 \mathrm{kgCO}_{2} \mathrm{e} / \mathrm{t} \mathrm{FW}$ & Anaerobic digestion & (Banks, et al., 2011b) (Banks, et al., 2011a). \\
\hline Embodied emissions in mineral fertilizers & $\begin{array}{l}\mathrm{N} \text {-fertilizer: } 5.62 \mathrm{kgCO}_{2} \mathrm{e} / \mathrm{kg} \mathrm{N} \\
\text { P-fertilizer: } 1.47 \mathrm{kgCO}_{2} \mathrm{e} / \mathrm{kg} \mathrm{P}_{2} \mathrm{O}_{5} \\
\text { K-fertilizer: } 1.45 \mathrm{kgCO}_{2} \mathrm{e} / \mathrm{kg} \mathrm{K}_{2} \mathrm{O}\end{array}$ & Anaerobic digestion, Composting & (FAO, 2015; Kool, et al., 2012). \\
\hline Embodied emissions in grid electricity & $0.446 \mathrm{kgCO}_{2} \mathrm{e} / \mathrm{kWh}$ & $\begin{array}{l}\text { Anaerobic digestion, Incineration, } \\
\text { Landfill }\end{array}$ & (BEIS, 2017b). \\
\hline Composting Process & $44.26 \mathrm{kgCO}_{2} \mathrm{e} / \mathrm{t} \mathrm{FW}$ & Composting & (Kim \& Kim, 2010; Nilsson, 2013; Takata, et al., 2012) \\
\hline
\end{tabular}




\section{1}

\subsection{Transport Modelling}

2 We assume that waste food is transported from the retail outlet to the nearest appropriate facility

3 for each disposal option. Emissions are based on round trips of distance approximate to the square

4 root of the average land area served per site, calculated by dividing the number of each site type in

5 the UK (Table 4) by the total UK land area (see S.I. Transport). Resulting distances compared

6 favourably to the data used in the Waste and Resources Assessment Tool for the Environment

7 (WRATE) on average journey distances to landfills and incinerators (BEIS, 2017a). Vehicle type and

8 emissions data were taken from the most recent UK Government Department of Business, Energy

9 and Industrial Strategy dataset on GHG Reporting (BEIS, 2017b); emissions were converted from

$10 \mathrm{kgCO}_{2} \mathrm{e} / \mathrm{km}$ to $\mathrm{kgCO}_{2} \mathrm{e} / \mathrm{t} \mathrm{FW}$ by calculating average vehicle load (see S.I. Transport).

11 Table 4 Number of disposal sites for each disposal option

\begin{tabular}{llll}
\hline Disposal Option & Site Type & Number & Reference(s) \\
\hline $\begin{array}{lll}\text { Donation } \\
\text { Animal feed }\end{array}$ & Food banks \& redistribution centre & 2085 & (Guardian, 2017) (IFAN, 2017) \\
Anaerobic digestion & Animal feed Processing facility & 50 & Estimate \\
Composting & Anaerobic digestion facility & 266 & (WRAP, 2017) \\
Incineration & Composting facility & 330 & (WRAP, 2015) \\
Landfill & Municipal solid waste incinerator & 39 & (UKWIN, 2017) \\
& Non-hazardous operational landfill & 594 & (HM Revenue \& Customs, 2016) \\
\hline
\end{tabular}

12

\subsection{Processing Facility/End of Life Destination Modelling}

\subsubsection{Donation}

15 In the donation scenario, unsold ("waste") food is passed on to end consumers at the donation site, without incurring any further emissions except for those related to transport. We assume that

17 refrigeration emissions are the same as would be incurred by households. The number of donation 
sites in the UK was taken as the combined total of independent food banks (712) identified by the Independent Food Aid Network food banks as of May 2017 (IFAN, 2017), and redistribution centres (1373) operating within the Trussell Trust network (Guardian, 2017). All donated food is assumed to be passed on to consumers, who are then assumed to waste the same proportion of each food type as do supermarket customers (i.e. donated and purchased food are treated the same in our analysis). Emissions mitigated by donation $\left(M_{D}\right)$ are equal to the emissions embodied in the food at the supermarket store $\left(M_{D}=E_{\text {store }}\right)$.

\subsubsection{Animal Feed}

In the animal feed scenario, food waste is converted to wet animal feed by being shredded, with addition of necessary substrates, incurring emissions ( $\left.E_{A F}\right)$. The value used for $E_{A F}$ was taken as the average of two previously reported values (Kim \& Kim, 2010; Takata, et al., 2012). For the purposes of this study, the production of wet feed was deemed the end-point of the disposal option, so onward transport was not considered. We assume that food-waste derived animal feeds replace a mix of two selected conventional feeds (oats and soybean meal) (Eriksson, et al., 2015), mitigating the emissions that would otherwise have occurred from the production of these feeds $\left(\mathrm{M}_{\mathrm{AF}}\right)$. The mass of oats and soybean meal replaced was based on the energy density (kcal/100 g) and protein density (g/100 g) of each food relative to those of oats and soybean meal. The embodied emissions in oats and soybean meal feeds were taken to be $380 \mathrm{kgCO}_{2} \mathrm{e} / \mathrm{t}$ and $2700 \mathrm{kgCO}_{2} \mathrm{e} / \mathrm{t}$ respectively, including emissions from production, transport and land-use change (Mogensen, et al., 2012). The energy and protein contents of Bread and Cheese were based on data for Wheat Bread (Item Code 18064) and Cheddar Cheese (Item Code 1009) taken from the United States Department of Agriculture (USDA) food composition database (USDA, 2017). Energy and protein contents of F\&V,

Fish, Meat, Oats and Soybean Meal were calculated from the USDA food composition data (USDA, 2017) for various relevant commodities listed in the Food and Agriculture Organisation (FAO) food 
balance sheets (FAO, 2016), weighted by FAO food balance sheet data on UK supply tonnage for each commodity (FAO, 2016). Methodology details are described in S.I. Nutritional Profiles and S.I. Animal Feed.

\subsubsection{Anaerobic Digestion}

In the anaerobic digestion scenario, food waste is converted to biogas and digestate at a digestion facility. Emissions incurred at the facility $\left(E_{A D}\right)$ were taken to be those associated with the parasitic electricity and heat requirement of the digestion process, (183.7 kWh/t heterogeneous FW) (Banks, et al., 2011b), proportioned to the total solids (TS) content of the food (see S.I Anaerobic Digestion), plus the emissions from natural gas used during on-site electricity generation $\left(0.96 \mathrm{kgCO}{ }_{2} \mathrm{e} / \mathrm{t} \mathrm{FW}\right)$ (Banks, et al., 2011a). All biogas is assumed to be captured and the methane combusted to generate electricity, mitigating emissions which would otherwise have occurred in the generation of grid electricity $\left(\mathrm{M}_{\mathrm{AD}, \mathrm{GE}}\right)$, while the non-combustible $\mathrm{CO}_{2}$ is simply released, without incurring further emissions, since it is of biogenic origin. Digestate substitutes for mineral fertilizers $\left(M_{A D}, M F\right)$, mitigating the emissions that incur during the production of nitrogen $(\mathrm{N})$, phosphorous $(\mathrm{P})$ and potassium (K) fertilizers. Total nutrient contents of input food-materials are typically not significantly altered by the anaerobic digestion process (WRAP, 2016), thus we have assumed that no NPK losses occur during the digestion process.

Methane generation potentials $\left(\mathrm{m}^{3} \mathrm{CH}_{4} / \mathrm{t} \mathrm{FW}\right)$ were calculated using Equation 1 (Eriksson, et al., 2015), where VS is the percentage volatile solids and Specific Production Factor $\left(\mathrm{m}^{3} \mathrm{CH}_{4} / \mathrm{t} \mathrm{VS}\right)$ is the average volume of methane generated per tonne of volatile solids of a given food type. VS values were calculated from USDA total solids (TS) data (Table 2) and VS/TS ratios (Carlsson \& Uldal, 2009). 

$\mathrm{kWh} / \mathrm{m}^{3}$ ) using a 35\% conversion efficiency factor (Banks, 2009). The average emission factor for UK grid electricity was then applied (BEIS, 2017b).

67

Emissions mitigated by use of the digestate produced $\left(M_{A D}, M F\right)$ were based on the nitrogen ( $\left.N\right)$, phosphorous (P) and potassium (K) content of the undigested food. Nitrogen contents were approximated from protein contents by the Kjedahl method, where nitrogen mass is taken to be 4/25 that of protein (AOAC, 2000). Phosphorous and potassium contents were taken directly from the USDA food composition database (USDA, 2017) for Wheat Bread (Item Code 18064) and Cheddar Cheese (Item Code 1009), and weighted by UK supply tonnage of relevant commodities listed in the FAO food balance sheets for F\&V, Fish and Meat, using identical methods to those used in the calculation of $M_{A F}$ (see S.I Feed and Fertilizer Replacement). Phosphorous and potassium contents were then converted to phosphate $\left(\mathrm{P}_{2} \mathrm{O}_{5}\right)$ and potassium oxide $\left(\mathrm{K}_{2} \mathrm{O}\right)$ contents, based on relative molecular masses, to quantify mineral fertilizer replacement. Individual embodied emissions in nitrogen, phosphorous and potassium fertilizers were taken from FAO data for Western Europe (FAO, 2015; Kool, et al., 2012). We assume that food-based digestates contain very little lignin and thus do not make a significant contribution to long term soil carbon sequestration.

\subsubsection{Composting}

In our composting scenario, we assume composting takes place at a commercial facility in an openwindrow system, with optimal temperature and concentrations of carbon, nitrogen and oxygen maintained throughout, ensuring complete aerobic composting, with the process meeting EU regulations. Some non-biogenic emissions are incurred in the composting process $\left(E_{c}\right)$, because diesel and electricity are used at the facility and additives are used for maintaining the aerobic 
conditions of the compost. Our $\mathrm{E}_{\mathrm{C}}$ value was taken as the average of those from three sources (Kim \& Kim, 2010; Nilsson, 2013; Takata, et al., 2012). Compost has value as both a fertilizer and soil conditioner (WRAP, 2016). Here we assume it is used as a mineral fertilizer replacement and hence emissions mitigated by its use to replace mineral fertilizer $\left(M_{c}\right)$ were calculated in the same way as for digestate in the anaerobic digestion scenario. As shown in Table 1 , we assume that $6 \%$ of the nitrogen is lost during composting (Pardo, et al., 2015). The same assumption concerning soil carbon sequestration used in the Anaerobic Digestion scenario is applied to food-based composts.

\subsubsection{Incineration (with electricity generation)}

In the incineration scenario, it is assumed that food waste is combusted completely in a municipal solid waste (MSW) incinerator, without incurring any non-biogenic emissions. Volumes of ash were assumed to be negligible and hence emissions arising from disposal of the ash were not considered. Net thermal energy from combustion was used to generate electricity on site, mitigating emissions that would otherwise have occurred from grid electricity generation $\left(M_{1}\right)$.

$M_{1}$ values were calculated using Equation 2, where N.E.R is net energy released, $\eta_{\mathrm{el}}$ is electrical conversion efficiency and $\mathrm{Grid}_{\mathrm{el}}$ is the emissions intensity of grid electricity. A value of $22 \%$ was used for $\eta_{e l}$ (Baddeley, et al., 2011). N.E.R was calculated using Equation 3, where $E_{c}$ is the energy content in the food, $W_{C}$ is the water content, and $W_{B}$ is the energy required to heat a unit of water to boiling point and then to boil it. $E_{C}$ was calculated from USDA and FAO data as previously described (FAO, 2016; USDA, 2017). WC data for Wheat Bread (Item Code 18064) and Cheddar Cheese (Item Code 1009) taken from the USDA food composition database (USDA, 2017) were applied to Bread and Cheese respectively. The $W_{c}$ of Meat was taken as the average water content of typical common raw meats (USDA, 2013). The $W_{C}$ of F\&V and Fish were approximated from USDA data (USDA, 2017) on the water contents of representative foods commonly consumed in the UK (for F\&V: apples, 
bananas, grapes, oranges, tomatoes, carrots, peas and lettuce; for Fish: tuna, salmon, cod and prawns). $W_{B}$ was calculated using Equation 4, where $T_{1}$ is the boiling temperature of water (373K), $T_{2}$ is the starting temperature of the water (taken as $298 \mathrm{~K}$ ), $\mathrm{W}_{\text {sp.H.c }}$ is the specific heat capacity of water $(4.19 \mathrm{KJ} / \mathrm{kg} / \mathrm{K})$ and $\mathrm{W}_{\text {L.H.C }}$ is the latent heat of vaporisation of water $(2257 \mathrm{~kJ} / \mathrm{kg})$.

Equation 2:

$$
M_{I}=N \cdot E \cdot R \times \eta_{e l} \times G r i d_{e l}
$$

Equation 3:

$$
N . E . R=E_{C}-\left(W_{C} \times W_{B}\right)
$$

\section{Equation 4:}

$$
W_{B}=\left[\left(T_{1}-T_{2}\right) \times W_{\text {Sp.H.C }}\right]+W_{\text {L.H.C }}
$$

In place of a process emissions factor, gross thermal energy outputs were reduced by $15.5 \%$ to mimic the parasitic heat loss to the walls of the incinerator (Nixon, et al., 2013). In cases where net energy output was negative, i.e. thermal energy had to be inputted into the incinerator to achieve complete combustion, the thermal energy was increased by $15.5 \%$.

\subsubsection{Landfilling (with and without gas collection)}

121 When food is deposited in landfill, it decomposes over time under anoxic conditions producing landfill gas (LFG), mainly methane $\left(\mathrm{CH}_{4}\right)$ and $\mathrm{CO}_{2}$. Over time some of the methane is oxidised to $\mathrm{CO}_{2}$ in covering soils. The majority of methane generated within UK landfills is flared or utilised (Gregory, et al., 2003). We investigate three landfill scenarios. In the first we assume best practice in which $70 \%$ of gases are collected and used for electricity generation. In the second we assume, allowing for some leakage, that $70 \%$ of gases are collected and flared (i.e. converted to $\mathrm{CO}_{2}$ and water). In the third scenario it is assumed that produced gases are simply vented to the atmosphere. For all three scenarios it is assumed that food is immediately buried on arrival, then left undisturbed, without incurring onsite transport-related emissions. The number of landfills in the UK was taken 
Revenue \& Customs, 2016b) and Scotland (SEPA, 2015). Methane emissions ( $\left.E_{L F}\right)$ where calculated by Equation 5 (IPCC, 2006), where $\mathrm{CH}_{4}$ generated is calculated in the same way as described in section 2.2.3. Anaerobic Digestion $\mathrm{CH}_{4}$ oxidised is the proportion of generated methane oxidised to $\mathrm{CO}_{2}$ in covering soils. Oxidation rates of $20 \%$ and $10 \%$ were applied for landfills with and without gas collection systems respectively (EPA, 2015). Where gas is flared we assume $100 \%$ destruction efficiency of $\mathrm{CH}_{4}$ to $\mathrm{CO}_{2}$. Where electricity is generated, mitigation is calculated in the same way as for the Anaerobic Digestion scenario.

\section{Equation 5:}

$$
\mathrm{CH}_{4} \text { emitted }=\left(\mathrm{CH}_{4} \text { generated }-\mathrm{CH}_{4} \text { collected }\right) \times\left(1-\% \mathrm{CH}_{4} \text { oxidised }\right)
$$

\subsection{Out of Scope Emissions and Uncertainties}

Several activities are outside of the system boundaries shown in Figure 2 and thus any emissions associated with these activities are excluded from evaluation. Specifically, for all scenarios, the following activities were excluded from the evaluation: energy consumed at facilities that is not directly used for food waste conversion; trace gas emissions other than carbon dioxide, methane and nitrous oxide; facility construction and maintenance; local heating; employee activities at sites; and transport vehicle manufacture. For anaerobic digestion, composting and landfill scenarios, onsite vehicular diesel emissions, emissions from transport and land application of digestate and compost, and emissions mitigated though carbon sequestration were excluded from the analysis.

Transport and treatment of wastewater and other wastes were also excluded, as it was assumed for simplification that no wastes were generated in any scenarios. Similarly, it was assumed that volumes of fly and bottom ash from incineration of food waste were negligible, since it was assumed that food waste did not include packaging and therefore was $100 \%$ organic matter. All life cycle analyses contain uncertainties that are difficult to quantify. Values used here for the embodied 
emissions in foods are derived from a number of secondary sources, selected on the basis of fit to the specific supply chains used by the case study retailer and credibility of the sources. Emissions factors quotes by different sources generally agree to within a factor of two. Uncertainty around transport emissions arises from both the emissions factors used and the assumptions relating to average distances. Both are also estimated to be accurate to within a factor of two. Overall transport emissions are a small component of all of our scenarios, making their uncertainty less important. Uncertainty also exists as to emissions and other outputs arising from the different disposal processes of composting, anaerobic digestion, incineration and landfill, although less so than for the upstream emissions, since they can be directly measured. The core findings in this paper are sufficiently clear cut as to be resilient to the uncertainties listed above.

\section{Results and Discussion}

Table 5 shows the emissions (arising or mitigated) through every term considered in each disposal option. Transport emissions occur in each disposal option, and are most influenced by the number of disposal sites, and consequently the distance that must be travelled. Refrigeration increases transportation emissions by a third relative to non-refrigerated transportation. Further emissions are incurred from processing of food waste in feed conversion, anaerobic digestion, composting and all landfilling options. Conversion of food waste to wet animal feed requires minimal inputs, incurring less emissions than does transportation. The processes of anaerobic digestion and composting are more energy intensive in our evaluation, however incurred emissions are still a fraction of those resulting from all landfill scenarios. Water (and thus volatile solids) content and specific methane production potential are the controlling factors in methane production. Relatively watery plant-derived foods (F\&V) incur least methane emissions, whilst energy-rich animal-derived foods (Cheese, Fish and Meat) incur the most. 
Table 5. GHG emissions occurring at each step of food waste disposal pathways, for five food types.

\begin{tabular}{|c|c|c|c|c|c|c|c|}
\hline \multirow[t]{2}{*}{ Term } & \multirow[t]{2}{*}{ Symbol } & \multicolumn{6}{|c|}{ Emissions (kg CO2e / tonne of food) } \\
\hline & & Bread & Cheese & F\&V & Fish & Meat & $\begin{array}{c}\text { Weighted } \\
\text { Average }\end{array}$ \\
\hline \multicolumn{8}{|l|}{ Incurred Emissions } \\
\hline Transport, donation & $\mathrm{T}_{\mathrm{D}}$ & 6 & 8 & 6 & 8 & 8 & 7 \\
\hline Transport, animal feed & $\mathrm{T}_{\mathrm{AF}}$ & 14 & 14 & 14 & 14 & 14 & 14 \\
\hline $\begin{array}{l}\text { Transport, anaerobic } \\
\text { digestion }\end{array}$ & $\mathrm{T}_{\mathrm{AD}}$ & 6 & 6 & 6 & 6 & 6 & 6 \\
\hline Transport, composting & $\mathrm{T}_{\mathrm{C}}$ & 5 & 5 & 5 & 5 & 5 & 5 \\
\hline Transport, incineration & $\mathrm{T}_{1}$ & 16 & 16 & 16 & 16 & 16 & 16 \\
\hline Transport, landfill & $T_{L F}$ & 4 & 4 & 4 & 4 & 4 & 4 \\
\hline Feed conversion process & $\mathrm{E}_{\mathrm{AF}}$ & 7 & 7 & 7 & 7 & 7 & 7 \\
\hline Anaerobic digestion process & $E_{A D}$ & 163 & 159 & 43 & 67 & 89 & 89 \\
\hline Composting process & $\mathrm{E}_{\mathrm{C}}$ & 44 & 44 & 44 & 44 & 44 & 44 \\
\hline $\begin{array}{l}\mathrm{CH}_{4} \text { release, } 70 \% \mathrm{CH}_{4} \text { capture } \\
\text { landfill }\end{array}$ & $E_{L F 70}$ & 848 & 1339 & 408 & 980 & 1333 & 791 \\
\hline $\begin{array}{l}\mathrm{CH}_{4} \text { release, } 0 \% \mathrm{CH}_{4} \text { capture } \\
\text { landfill }\end{array}$ & $\mathrm{E}_{\mathrm{LFO}}$ & 3181 & 5021 & 1531 & 3676 & 4999 & 2965 \\
\hline \multicolumn{8}{|l|}{ Mitigated Emissions } \\
\hline Consumption of donated food & $M_{D}$ & 1400 & 13700 & 2500 & 2700 & 13800 & 5590 \\
\hline $\begin{array}{l}\text { Crop-based animal feed } \\
\text { replacement }\end{array}$ & $\mathrm{M}_{\mathrm{AF}}$ & 364 & 1005 & 36 & 1121 & 735 & 369 \\
\hline $\begin{array}{l}\text { Grid electricity replacement, } \\
\text { anaerobic digestion }\end{array}$ & $\mathrm{M}_{\mathrm{AD}, \mathrm{GE}}$ & 340 & 537 & 164 & 393 & 535 & 317 \\
\hline $\begin{array}{l}\text { Mineral fertilizer } \\
\text { replacement, anaerobic } \\
\text { digestion }\end{array}$ & $\mathrm{M}_{\mathrm{AD}, \mathrm{MF}}$ & 103 & 222 & 17 & 187 & 147 & 85 \\
\hline $\begin{array}{l}\text { Mineral fertilizer } \\
\text { replacement, composting }\end{array}$ & $\mathrm{M}_{\mathrm{C}, \mathrm{MF}}$ & 97 & 210 & 16 & 176 & 139 & 80 \\
\hline $\begin{array}{l}\text { Grid electricity replacement, } \\
\text { incineration }\end{array}$ & $M_{1, G E}$ & 177 & 283 & -36 & 47 & 130 & 74 \\
\hline $\begin{array}{l}\text { Grid electricity replacement, } \\
70 \% \mathrm{CH}_{4} \text { capture landfill with } \\
\text { gas utilisation }\end{array}$ & $\mathrm{M}_{\mathrm{LF70,GE}}$ & 238 & 376 & 115 & 275 & 375 & 222 \\
\hline
\end{tabular}

180 Mitigated emissions are greatest through donation of waste food, with consumption of the food by 181 people negating all embodied emissions at the supermarket checkout. Significant emissions can be 182 mitigated through replacement of crop-based feeds (especially soybean meal) though food-to-feed conversion. Appreciable emissions are also mitigated by electricity generation in anaerobic 
digestion and, for some foods, by incineration, although the degree of this mitigation will fall if grid electricity becomes less carbon intensive in the future. Some emissions are also mitigated by mineral fertilizer replacement with digestate and compost. In the case of landfill, there is an important benefit to gas utilisation rather than flaring off.

Table 6 shows the net emissions resulting from disposal of waste food through each disposal option, along with the mass-weighted average across the five food types and the disposal option priority order, based on the weighted average emissions. With the least incurred emissions and most emissions mitigated, donation unsurprisingly has the most negative net emissions of all disposal options regardless of food type. Conversely landfilling leads to the greatest net emissions, increasing proportional to the volume of uncaptured methane released. Reasonable weighted average net negative emissions are achieved by conversion of waste food to animal feed and anaerobic digestion, with superior net emissions mitigation through conversion to animal feed than anaerobic digestion for all food types considered with the exception of F\&V. We find composting and incineration to have similar weighted average net emissions, and both are preferable to landfill, for which weighted average net emissions are highly positive even for a modern landfill with efficient gas collection and utilisation. Figure 3 shows the order of disposal options for each food type from least to most GHG emissions. Interestingly, the priority orders for all five foods (with the exception 201 of Fish) and the mass weighted average order deviate slightly from hierarchies published by both 202 US and European government agencies (Figure 3), which place animal feed, anaerobic digestion, 203 composting and incineration in places 2, 3, 4 and 5 respectively (EPA, 2017; Commission Directive 204 2008/98/EC). 
Table 6. Net emissions from each disposal option

\begin{tabular}{|c|c|c|c|c|c|c|c|c|}
\hline \multirow{2}{*}{$\begin{array}{l}\text { Disposal } \\
\text { Option }\end{array}$} & \multirow[t]{2}{*}{ Formula } & \multicolumn{6}{|c|}{ Emissions $\left(\mathrm{kg} \mathrm{CO}_{2} \mathrm{e} / \mathrm{t} \mathrm{FW}\right)$} & \multirow{2}{*}{$\begin{array}{c}\text { Weighted } \\
\text { Disposal } \\
\text { Priority }\end{array}$} \\
\hline & & Bread & Cheese & F\&V & Fish & Meat & $\begin{array}{c}\text { Weighted } \\
\text { Average }\end{array}$ & \\
\hline Donation & $T_{D}-M_{D}$ & -1394 & -13692 & -2494 & -2692 & -13792 & -5583 & 1 \\
\hline Animal feed & $T_{A F}+E_{A F}-M_{A F}$ & -342 & -983 & -15 & -1100 & -714 & -347 & 2 \\
\hline $\begin{array}{l}\text { Anaerobic } \\
\text { digestion }\end{array}$ & $\begin{array}{c}T_{A D}+E_{A D}-\left(M_{A D}\right. \\
\left.G E+M_{A D, M F}\right)\end{array}$ & -280 & -601 & -137 & -513 & -593 & -314 & 3 \\
\hline Composting & $T_{C}+E_{c}-M_{c, M F}$ & -48 & -161 & 33 & -127 & -89 & -31 & 5 \\
\hline Incineration & $T_{1}-M_{1, G E}$ & -161 & -266 & 52 & -31 & -114 & -58 & 4 \\
\hline Landfill, $70 \%$ & & & & & & & & \\
\hline $\begin{array}{l}\mathrm{CH}_{4} \text { capture } \\
\text { with gas } \\
\text { utilisation }\end{array}$ & $\begin{array}{c}T_{L}+E_{L F 70}- \\
M_{L F 70, G E}\end{array}$ & 614 & 967 & 298 & 709 & 963 & 573 & 6 \\
\hline $\begin{array}{l}\text { Landfill, } 70 \% \\
\mathrm{CH}_{4} \text { capture } \\
\text { with flaring }\end{array}$ & $\mathrm{T}_{\mathrm{LG}}+\mathrm{E}_{\mathrm{LF70}}-\mathrm{M}_{\mathrm{LF} 20}$ & 852 & 1343 & 412 & 984 & 1337 & 795 & 7 \\
\hline $\begin{array}{l}\text { Landfill, } 0 \% \mathrm{CH}_{4} \\
\text { capture }\end{array}$ & $T_{L}+E_{L F 0}$ & 3185 & 5025 & 1535 & 3680 & 5003 & 2969 & 8 \\
\hline
\end{tabular}

207

\begin{tabular}{|c|c|c|c|c|c|c|}
\hline Bread & Donation & Animal Feed & $\begin{array}{l}\text { Anaerobic } \\
\text { Digestion }\end{array}$ & Incineration & Composting & Landfill \\
\hline Cheese & Donation & Animal Feed & $\begin{array}{l}\text { Anaerobic } \\
\text { Digestion }\end{array}$ & Incineration & Composting & Landfill \\
\hline $\mathrm{F} \& \mathrm{~V}$ & Donation & $\begin{array}{l}\text { Anaerobic } \\
\text { Digestion }\end{array}$ & Animal Feed & Composting & Incineration & Landfill \\
\hline Fish & Donation & Animal Feed & $\begin{array}{l}\text { Anaerobic } \\
\text { Digestion }\end{array}$ & Composting & Incineration & Landfill \\
\hline Meat & Donation & Animal Feed & $\begin{array}{l}\text { Anaerobic } \\
\text { Digestion }\end{array}$ & Incineration & Composting & Landfill \\
\hline $\begin{array}{l}\text { Neighted } \\
\text { Average }\end{array}$ & Donation & Animal Feed & $\begin{array}{l}\text { Anaerobic } \\
\text { Digestion }\end{array}$ & Incineration & Composting & Landfill \\
\hline $\begin{array}{l}\text { Agency } \\
\text { lierarchies }\end{array}$ & Donation & Animal Feed & $\begin{array}{l}\text { Anaerobic } \\
\text { Digestion }\end{array}$ & Composting & Incineration & Landfill \\
\hline
\end{tabular}

Figure 3 Disposal priority orders, in terms of GHG emissions, for all individual food types and the mass weighted average, are distinct from those reported by government agencies.

211 By setting absolute net emissions as a proportion of the embodied emissions of each food at the 212 supermarket checkout, we can quantify the extent to which the embodied emissions in each food 213 type can be mitigated (or otherwise) by each disposal option (Table 7). 
Table 7. Net mitigation as a percentage of embodied food emissions

\begin{tabular}{|c|c|c|c|c|c|c|}
\hline \multirow[t]{2}{*}{ Disposal Option } & \multicolumn{6}{|c|}{ Food Type } \\
\hline & Bread & Cheese & F\&V & Fish & Meat & Weighted Avg. \\
\hline Donation & $100 \%$ & $100 \%$ & $100 \%$ & $100 \%$ & $100 \%$ & $100 \%$ \\
\hline Animal feed & $24 \%$ & $7 \%$ & $1 \%$ & $41 \%$ & $5 \%$ & $6 \%$ \\
\hline Anaerobic digestion & $20 \%$ & $4 \%$ & $5 \%$ & $19 \%$ & $4 \%$ & $6 \%$ \\
\hline Composting & $3 \%$ & $1 \%$ & $-1 \%$ & $5 \%$ & $1 \%$ & $1 \%$ \\
\hline Incineration & $11 \%$ & $2 \%$ & $-2 \%$ & $1 \%$ & $1 \%$ & $1 \%$ \\
\hline $\begin{array}{l}\text { Landfill, } 70 \% \mathrm{CH}_{4} \text { capture with } \\
\text { gas utilisation }\end{array}$ & $-44 \%$ & $-7 \%$ & $-12 \%$ & $-26 \%$ & $-7 \%$ & $-10 \%$ \\
\hline $\begin{array}{l}\text { Landfill, } 70 \% \mathrm{CH}_{4} \text { capture with } \\
\text { flaring }\end{array}$ & $-61 \%$ & $-10 \%$ & $-16 \%$ & $-36 \%$ & $-10 \%$ & $-14 \%$ \\
\hline Landfill, $0 \% \mathrm{CH}_{4}$ capture & $-227 \%$ & $-37 \%$ & $-61 \%$ & $-136 \%$ & $-36 \%$ & $-53 \%$ \\
\hline
\end{tabular}

215

216 225 from landfill is particularly important.

\section{Conclusions}

Under all circumstances insuring food that cannot be sold is eaten by humans is the best disposal option available to a retailer, with respect to GHG emissions. In this option, additional emissions, incurred through transport, $<1 \%$ of those embodied in the food at the supermarket store. From a GHG perspective this is the only option which can be considered comparable to selling the food. Even if half of donated food is wasted and disposed of to a landfill with no gas collection infrastructure, this is still better than the next best option, conversion to animal feed.

Our analysis also clearly shows that disposal to landfill is the worst available option for all foods. Landfill emissions are particularly high for energy dense foods and hence diversion of these foods

If food is unfit for human consumption, conversion to animal feed is the best available option, followed by anaerobic digestion, for all five food types except $F \& V$, for which anaerobic digestion is preferable over conversion to animal feed. However, mitigation of the emissions embodied in the waste food is never higher than $41 \%$ for conversion to animal feed and $20 \%$ for anaerobic digestion, compared with $>99 \%$ for food donation. Our results indicate that incineration with energy recovery 
231 is preferable to composting for bread, cheese and meat, but not for F\&V or fish. In this respect our 232 food waste hierarchy differs from the US EPA and European Union published food waste hierarchies 233 (see Figure 3), though the EU hierarchy is based on a range of environmental criteria, not just GHG 234 emissions, and the US EPA hierarchy includes environmental, social and economic considerations.

Policy Implications

236 Our results show the importance of channelling all edible food waste from retail outlets to food banks, redistribution charities and other such organisations to ensure that as much unsold "waste"

238 food as possible is eaten by people. To that end, our study supports the development of policies encouraging the donation of all edible unsold food from food retail stores. Our data also shows that, for food unsuitable for human consumption, conversion to animal feed is the best option in terms 241 of net GHG emissions, followed by anaerobic digestion, for all food types except F\&V. Landfill, even 242 at a modern site capturing and utilising $70 \%$ of generated methane, is the worst option for all food 243 types by a clear margin. Our findings indicate that, from a GHG perspective, landfill should not be used for the disposal of waste food by retailers.

\section{Supplementary Information}

The supplementary information is contained in the Excel workbook: 'SI Greenhouse Gas Emissions of Food Waste Disposal Options for UK Retailers.xlsb'.

\section{References}

AOAC, 2000. Official Methods of Analysis of AOAC International. 17th ed. Association of Official Analytical Chemists (AOAC) International: Gaithersburg. 
Baddeley, A., Ballinger, A. \& Cullen, C., 2011. Development of a Greenhouse Gas Emissions Performance Standard for London's Municipal Waste: Revised Appendices, Appendix 4C, The Greater London Authority: London.

Banks, C., 2009. Optimising anaerobic digestion. Evaluating the Potential for Anaerobic Digestion to provide Energy and Soil amendment.. [Online]. Available at: https://www.forestry.gov.uk/pdf/rrps AD250309 optimising anaerobic digestion.pdf/\$file/rrps AD250309 optimising anaerobic digestion.pdf [Accessed 1902 2018].

Banks, C., Chesshire, M., Heaven, S. \& Arnold, R., 2011b. Anaerobic digestion of sourcesegregated domestic food waste: performance assessment by mass and energy balance. Bioresource Technology, 102(2), pp. 612-620.

Banks, C. et al., 2011a. Biocycle anaerobic digester: performance and benefits. In Proceedings of the Institution of Civil Engineers-Waste and Resource Management, 164(3), pp. 141-150.

BEIS, 2017a. 2017 Government GHG Conversion Factors For Company Reporting, Methodology Paper for Emission Factors - Final Report. [Online]. Available at: https://www.gov.uk/government/uploads/system/uploads/attachment data/file/635628/2017 methodology paper_FINAL_MASTER v01-01_Simon.pdf [Accessed 1902 2018].

BEIS, 2017b. Greenhouse gas reporting: conversion factors 2017. [Online] Available at: https://www.gov.uk/government/publications/greenhouse-gas-reportingconversion-factors-2017 [Accessed 1902 2018].

Berners-Lee, M. \& Hoolohan, C., 2012. The greenhouse gas footprint of Booths, Lancaster: Small World Consulting Ltd.

Carlsson, M. et al., 2015. Importance of Food Waste Pre-Treatment Efficiency for Global Warming Potential in Life Cycle Assessment of Anaerobic Digestion Systems.. Resources, Conservation and Recycling, Volume 102, pp. 58-66.

Carlsson, M. \& Uldal, M., 2009. Substrate Handbook for biogas production. Swedish Technical Center.

DEFRA \& APHA, 2014a. Animal by-product categories, site approval, hygiene and disposal. [Online]. Available at: https://www.gov.uk/guidance/animal-by-product-categories-site-approvalhygiene-and-disposal\#disposing-of-abps [Accessed 1902 2018].

DEFRA \& APHA, 2014b. How food businesses must dispose of food and former foodstuffs. [Online]. Available at: https://www.gov.uk/guidance/how-food-businesses-must-dispose-of-foodand-former-foodstuffs [Accessed 1902 2018].

DEFRA \& APHA, 2014c. Using animal by-products to make pet food. [Online] Available at: https://www.gov.uk/guidance/using-animal-by-products-to-make-pet-food [Accessed 1902 2018]. 
DEFRA, 2011a. Government review of waste policy in England 2011. [Online]

Available at: https://www.gov.uk/government/publications/government-review-of-waste-policyin-england-2011 [Accessed 1902 2018].

DEFRA, 2014. Energy from waste: a guide to the debate. [Online]

Available at: https://www.gov.uk/government/publications/energy-from-waste-a-guide-to-thedebate [Accessed 1902 2018].

EPA, 2015. WARM Version 13, s.I.: United States Environmental Protection Agency (US EPA).

[Online]. Available at: https://www.epa.gov/warm/versions-waste-reduction-model-warm\#13

EPA, 2017. Sustainable Management of Food, Food Recovery Hierarchy. [Online]

Available at: https://www.epa.gov/sustainable-management-food/food-recovery-hierarchy

[Accessed 1902 2018].

Eriksson, M., Strid, I. \& Hansson, P., 2015. Carbon Footprint of Food Waste Management Options in the Waste Hierarchy-a Swedish Case Study. Journal of Cleaner Production, Volume 93, pp. $115-125$.

European Commission, 2008/98/EC. Commission Directive 2008/98/EC of the European Parliament and of the Council of 19 November 2008 on waste and repealing certain Directives.. Official Journal of the European Union, Volume 312, p. 3-30.

European Commission, No 1069/2009. Commission Regulation (EC) No 1069/2009 of the European Parliament and of the Council of 21 October 2009. Official Journal of the European Union, Volume 300, pp. 1-33.

European Commission, No 1169/2011. Commission Regulation (EU) No 1169/2011 of the European Parliament and of the Council of 25 October 2011 on the provision of food information to consumers.... Official Journal of the European Union, 25 10, Volume 304, p. 18-63.

European Commission, No 142/2011. Commission Regulation (EU) No 142/2011 of 25 February 2011. Official Journal of the European Union, 25 02, Volume 54, pp. 1-254.

European Commission, No 68/2013. Commission Regulation (EU) No 68/2013 of 16 January 2013 on the Catalogue of feed materials. Official Journal of the European Union, 16 01, Volume 29, pp. 1-64.

FAO, 2015. Global database of GHG emissions related to feed crops. A life cycle inventory, Rome: Food and Agriculture Organisation of the United Nations (FAO) and Livestock Environmental Assessment and Performance Partnership (LEAPP).

FAO, 2016. Food Balance Sheets. [Online] Available at: http://www.fao.org/faostat/en/\#data [Accessed 1902 2018]. 
Gregory, R., Gillett, A. \& Bradley, D., 2003. Methane Emissions from Landfill Sites in the UK, Final Report. Land Quality Management Ltd. For: Department of Food, Agriculture and Rural Affairs (DEFRA).

Gregory, R. et al., 2014. Review of Landfill Methane Emissions Modelling, Nottingham: Golder Associates (UK) Ltd.

Guardian, 2017. Report reveals scale of food bank use in the UK. [Online] Available at: https://www.theguardian.com/society/2017/may/29/report-reveals-scale-of-foodbank-use-in-the-uk-ifan [Accessed 1902 2018].

HM Revenue \& Customs, 2016a. Landfill Tax: increase in rates. [Online] Available at: https://www.gov.uk/government/publications/landfill-tax-increase-in-rates/landfilltax-increase-in-rates [Accessed 1902 2018].

HM Revenue \& Customs, 2016b. List of registered Landfill site operators. [Online] Available at: https://www.gov.uk/government/publications/landfill-tax-site-operators [Accessed 1902 2018].

HM Revenue \& Customs, 2016. List of registered Landfill site operators. [Online] Available at: https://www.gov.uk/government/publications/landfill-tax-site-operators [Accessed 1902 2018].

IFAN, 2017. Mapping the UK's Independent Food Banks. [Online] Available at: http://www.foodaidnetwork.org.uk/mapping [Accessed 1902 2018].

IPCC, 2006. IPCC Guidelines for National Greenhouse Gas Inventories (2006). Intergovernmental Panel on Climate Change (IPCC).

IPCC, 2007. Contribution of Working Group lii to the Fourth Assessment Report of the Intergovernmental Panel on Climate Change. [Metz, B., Davidson, O. R., Bosch, P. R., Dave, R., Meyer, L. A. (Editors)], Cambridge, UK and New York, USA: Cambridge University Press.

Kim, M. \& Kim, J., 2010. Comparison through a LCA Evaluation Analysis of Food Waste Disposal Options from the Perspective of Global Warming and Resource Recovery. Science of The Total Environment, 408(19), pp. 3988-4006.

Kool, A., Marinussen, M. \& Blonk, H., 2012. LCl data for the calculation tool Feedprint for greenhouse gas emissions of feed production and utilization. GHG Emissions of $N, P$ and $K$ fertilizer production, Blonk Consultants: (Ed.).

Lancashire County Council, 2016. Trade Advice Document, Disposal of surplus food. [Online] Available at: http://www.lancashire.gov.uk/business/trading-standards/trading-advice1/details.aspx?doc id=152072\&cat id=1 [Accessed 1902 2018].

Mogensen, L. et al., 2012. Greenhouse gas emissions from feed production and enteric fermentation of rations for dairy cows. In: Book of Abstracts of the 63th Annual Meeting of the 
360

European Association for Animal Production (EAAP). Bratislava, Slovakia: 27-31 August 2012, p. 294.

Nilsson, H., 2013. Integrating Sustainability in the Food Supply Chain: Two Measures to Reduce the Food Wastage in a Swedish Retail Store.

Nixon, J. et al., 2013. A comparative assessment of waste incinerators in the UK. Waste Management, 33(11), pp. 2234-2244.

Pardo, G., Moral, R., Aguilera, E. \& Del Prado, A., 2015. Gaseous emissions from management of solid waste: A systematic review. Global Change Biol., Volume 21, pp. 1313-1327.

Rajaeifar, M.A., Tabatabaei, M., Ghanavati, H., Khoshnevisan, B. and Rafiee, S., 2015. Comparative life cycle assessment of different municipal solid waste management scenarios in Iran. Renewable and Sustainable Energy Reviews, 51, pp.886-898.

ReFood, 2014. Vision 2020: UK roadmap to zero waste to landfill. [Online]. Available at: http://www.vision2020.info/assets/pdf/Vision_2020_roadmap.pdf [Accessed 1902 2018].

San Martin, D., Ramos, S. \& Zufía, J., 2016. Valorisation of Food Waste to Produce New Raw Materials for Animal Feed. Food Chemistry, Volume 198, pp. 8-74.

SEPA, 2015. Waste sites and capacity information excel. [Online] Available at: https://www.sepa.org.uk/environment/waste/waste-data/waste-datareporting/waste-site-information/waste-sites-and-capacity-excel/ [Accessed 1902 2018].

Takata, M. et al., 2012. The effects of recycling loops in food waste management in Japan: based on the environmental and economic evaluation of food recycling. . Science of the total environment, Volume 4.

Tesco, 2014. Tesco and Society Report 2014. [Online]. Available at: https://www.tescoplc.com/media/1184/tesco and society review 2014.pdf [Accessed 1902 2018].

UKWIN, 2017. Table of Potential, Existing and Prevented Incinerators. [Online] Available at: http://ukwin.org.uk/resources/table/ [Accessed 1902 2018].

UN, 2015. General Assembly Resolution A/RES/70/1. Transforming Our World, the 2030 Agenda for Sustainable Development. [Online]

Available at: https://sustainabledevelopment.un.org/post2015/transformingourworld/publication [Accessed 1902 2018].

USDA, 2013. Water in Meat and Poultry. [Online] Available at: https://www.fsis.usda.gov/wps/portal/fsis/topics/food-safety-education/getanswers/food-safety-fact-sheets/meat-preparation/water-in-meat-and-poultry/ct index [Accessed 1902 2018]. 
USDA, 2017. USDA Food Composition Databases. [Online]

395 Available at: https://ndb.nal.usda.gov/ndb/ [Accessed 1902 2018].

396 Wadhwa, M. \& Bakshi, M., 2013. Utilization of fruit and vegetable wastes as livestock feed and 397 as substrates for generation of other value-added products. Rap Publication, Volume 4.

398 WRAP, 2015. Organics recycling industry status report 2015. WRAP. [Online]

399 Available at: http://www.wrap.org.uk/content/organics-recycling-industry-status-report-2015-0

$400 \quad$ [Accessed 1902 2018].

401 WRAP, 2016. Digestate and compost in agriculture: Good practice guidance. [Online]

402 Available at:

403 http://www.wrap.org.uk/sites/files/wrap/Digestate_compost_good_practice guide reference ve 404 rsion.pdf [Accessed 1902 2018].

405 WRAP, 2017. Estimates of Food Surplus and Waste Arisings in the UK. [Online]

406 Available at: http://www.wrap.org.uk/sites/files/wrap/Estimates \%20in the UK Jan17.pdf

407 [Accessed 1902 2018].

408 WRAP, 2017. Operational AD sites [Online Dataset]. [Online]

409 Available at: http://www.wrap.org.uk/content/operational-ad-sites [Accessed 1902 2018].

410

411

412 